\title{
High genetic differentiation of Aegla longirostri (Crustacea, Decapoda, Anomura) populations in southern Brazil revealed by multi-loci microsatellite analysis
}

\author{
M.L. Bartholomei-Santos, P.A. Roratto and S. Santos \\ Programa de Pós-Graduação em Biodiversidade Animal, \\ Centro de Ciências Naturais e Exatas, Universidade Federal de Santa Maria, \\ Santa Maria, RS, Brasil \\ Corresponding author: M.L. Bartholomei-Santos \\ E-mail: marliselbs@gmail.com
}

Genet. Mol. Res. 10 (4): 4133-4146 (2011)

Received March 14, 2011

Accepted August 18, 2011

Published November 22, 2011

DOI http://dx.doi.org/10.4238/2011.November.22.4

\begin{abstract}
Species with a broad distribution rarely have the same genetic make-up throughout their entire range. In some cases, they may constitute a cryptic complex consisting of a few species, each with a narrow distribution, instead of a single-, widely distributed species. These differences can have profound impacts for biodiversity conservation planning. The genetic differentiation of four populations of Aegla longirostri, a freshwater crab found in two geographically isolated basins in Rio Grande do Sul State, Brazil, was investigated by analyzing pentanucleotide multi-loci microsatellites in a heteroduplex assay. Although no morphological differences were evident, we found significant genetic differentiation among the four populations, based on $F_{\text {ST }}$ values and clustering analysis. This high level of differentiation may be indicative of cryptic species in these populations. If this hypothesis is correct, then the species occurring in the Ibicuí-Mirim
\end{abstract}


River, at the southern limit of the Atlantic Rain Forest, would be under threat, considering its very restricted distribution.

Key words: Population genetic structure; Heteroduplex assay; Anomuran crab; Conservation; Cryptic species

\section{INTRODUCTION}

Freshwater ecosystems hold an exceptional concentration of biodiversity. Species richness is greater than that of both marine and terrestrial ecosystems, when considering the habitat extent in freshwater ecosystems (Silk, 2005). On the other hand, the world's freshwater biodiversity is among the most threatened and deserves urgent conservation care (Abell, 2002; Pérez-Losada et al., 2009).

Estimating the species richness and endemism is essential for the conservation of biological diversity, and prioritizing habitats for conservation often relies on these estimates (Bickford et al., 2007). A growing number of recent genetic studies have unveiled the hidden biological diversity in the form of cryptic species (Hebert et al., 2004; Leese and Held, 2008; Russello et al., 2010). In this sense, the identification of cryptic species is essential not only for more accurate estimates but also for conservation (Cook et al., 2008), since some of them may disappear without even being known. In addition, incorrect lumping of several distinct species into one recognized species might impair the protection, if any of the lumped species is endangered (Frankham et al., 2004).

Recently, several cryptic species have been detected within freshwater crustaceans (Mathews et al., 2008; Munoz et al., 2009; Jesse et al., 2010). Nevertheless, nothing is known about cryptic species in freshwater anomuran crabs of the family Aeglidae.

The family Aeglidae has attracted researchers since its first species, Aegla laevis, was described. Several features make this family evolutionarily and ecologically unique: it is the only anomuran family entirely restricted to continental waters; the group originated near 75 Mya and diversified in only one extant and speciose genus (Pérez-Losada et al., 2004), Aegla, with near 70 species described and in process of description (Santos et al., 2009; Bond-Buckup et al., 2010; McLaughlin et al., 2010); although the extant species are present only in southern South America (Bond-Buckup and Buckup, 1994), there are fossil records of aeglids in marine strata from New Zealand (Feldmann, 1984) and Mexico (Feldmann et al., 1998); moreover, most Aegla species have a very narrow distributional range and there are several threatened species (Bond-Buckup et al., 2008; Pérez-Losada et al., 2004, 2009).

Little is known about the evolution of the species of this family. An intriguing feature of this group is its high diversity compared to crayfish of the family Parastacidae (Astacidea), also present in South America, with only 12 species described for this continent (Rudolph and Crandall, 2007). The known number of aeglids may be still underestimated given that more extensive sampling has led to the discovery of new species, and additional new species will be described (Santos et al., 2009; Bond-Buckup et al., 2010).

Clues for new species also come from molecular analysis. In a broad study, PérezLosada et al. (2004) sought to clarify aspects of the origin, taxonomic position, biogeography and systematics of the genus Aegla, through a phylogenetic analysis using one nuclear (18 rDNA) and four mitochondrial (12S e $16 \mathrm{~S}$ rDNA, COI, and COII) genes, which involved 
58 species. Pérez-Losada et al. (2004) reported that populations in some species, such as Aegla cholchol, Aegla jarai, Aegla parana, Aegla platensis, Aegla franciscana and Aegla marginata form non-monophyletic groups. These authors have suggested, based on the concept that populations whose groups are not monophyletic qualify as different species, that some populations within these six "species" may represent distinct species. Another species, Aegla longirostri, has been demonstrated to be monophyletic through Maximum Likelihood analysis and paraphyletic through Maximum Parsimony methodology. The specimens of the latter species were obtained from three distinct populations, but all from the same hydrographic basin (Taquari-Guaíba River, Brazil).

Some of these species, mainly those with a broader distribution, as A. longirostri, might represent cryptic species, which deserves special attention in relation to their real distribution, endemicity and conservation status.

Bond-Buckup et al. (2008) recognized 23 species of 63 species evaluated as under threat or endangered. The authors have pointed out the main factors responsible for the aeglids being under threat as their narrow distribution combined with the rapid degradation of their freshwater habitats, the establishment of extensive plantations of pine and Eucalyptus, the exaggerated use of pesticides in apple tree and potatoes cultivation, in addition to hog raising activities.

Studies on the genetic structure of aeglid species can help to clarify the evolutionary nuances of these animals, helping to resolve taxonomic uncertainties, unveiling cryptic species, identifying populations of concern, and contributing to trace conservation strategies. The species mentioned as paraphyletic by Pérez-Losada et al. (2004), as A. longirostri, are of special interest once they might represent unrecognized species.

Microsatellite loci are molecular markers that have been widely used in population genetics due to their high levels of polymorphism and their power to solve biological questions (Oliveira et al., 2006). Nevertheless, despite all their advantages, microsatellites are often difficult to isolate and to amplify, mainly in certain taxa (Meglécz et al., 2004). One of the frequent drawbacks found when isolating microsatellite loci is the isolation of a multi-loci microsatellite (microsatellite repeat with flanking regions also repeated in genome), which give a complex pattern of multiple bands when amplified. Frequently, this kind of loci is considered useless and it is discarded. However, some studies have made use of multi-loci microsatellites with success (Roratto et al., 2006; Bart et al., 2006; Mailllard et al., 2009).

The present study aimed to investigate the genetic structure of $A$. longirostri populations sampled in two neighboring, but geographically isolated, drainage basins, using a multiloci microsatellite as a molecular marker and a heteroduplex assay.

\section{MATERIAL AND METHODS}

\section{Specimen identification}

Individuals of Aegla longirostri from the four populations were identified using the diagnostic characters described in Bond-Buckup and Buckup (1994): a very long rostrum, styliform, carinate along its entire length; palmar crest rectangular, excavated; inner margin of ventral surface of ischium of chelipod with two robust spines with tubercles between them; anterior angle of ventral margin of epimeron 2 projected in a robust spine. 


\section{Sampling area}

In the central region of the State of Rio Grande do Sul, Brazil, four sampling points were established (Figure 1), all of them in environmentally protected locations, with gallery forests, clean water and rocky ground, which are habitat requirements for $A$. longirostri (BondBuckup, 2003). Descriptions of the sampling points are given in Table 1.

The individuals collected were transported to the laboratory in separate plastic bags and kept in aquariums until the DNA extraction procedure.
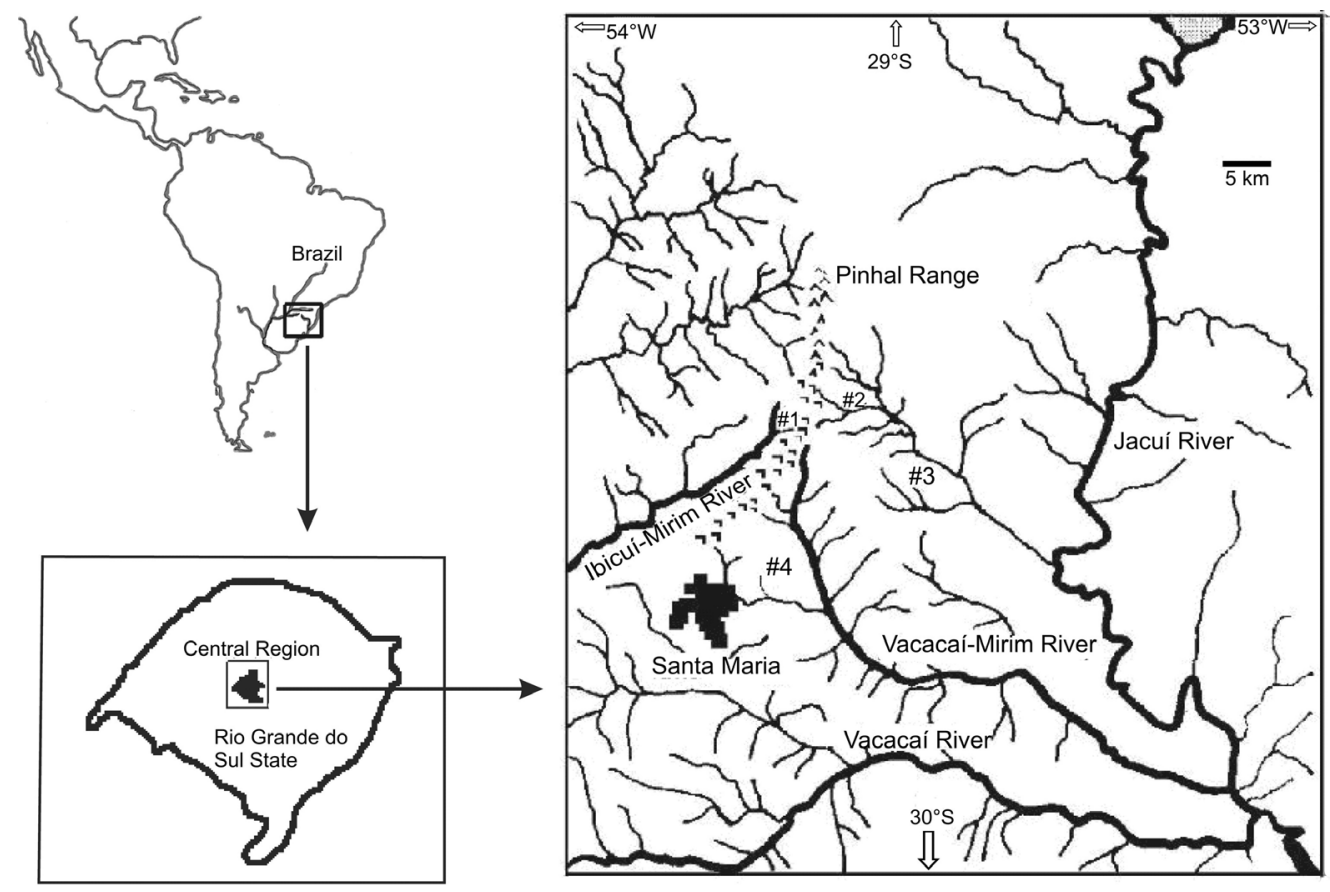

Figure 1. The sampling locations in the central part of the State of Rio Grande do Sul, Brazil.

\section{Isolation of the sequence containing a pentameric microsatellite}

Individuals were cryo-anesthetized before dissection. Total DNA was extracted from muscle tissue using the traditional phenol-chloroform protocol with some modifications, followed by purification with 13\% PEG 8,000/1.6 M NaCl (Bitencourt et al., 2006).

In order to assess the genetic variability among populations of $A$. longirostri from the two basins, a microsatellite was isolated using heterologous primers designed to amplify a nearly $260 \mathrm{bp}$ segment, containing a pentameric repetitive region within the U1snRNA gene complex, which is tandemly repeated in the genomes of the tapeworms Echinococcus multilocularis and Echinococcus granulosus (Bretagne et al., 1996; Roratto et al., 2006).

$\mathrm{PCR}$ was carried out in a $25 \mu \mathrm{L}$ reaction volume containing $100 \mathrm{ng}$ A. longirostri total DNA, $1.25 \mathrm{U}$ Taq DNA polymerase (Cenbiot), $100 \mu \mathrm{M}$ of each dNTP (Invitrogen), $10 \mathrm{mM}$ Tris-HCl, $50 \mathrm{mM} \mathrm{KCl}, 1.5 \mathrm{mM} \mathrm{MgCl}_{2}$ and 20 pmoles of each primer (Forward - 5'ATTGTC 


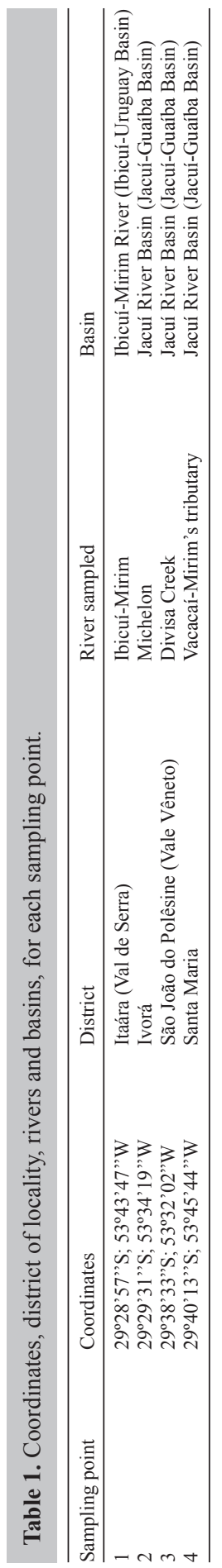


GTTGCCATCTCTCC3' and Reverse - 5'GCTCTCCATCACCACACATC3'). The negative control consisted of a reaction without DNA.

The PCR cycle program consisted of an initial denaturation step at $94^{\circ} \mathrm{C}$ for $5 \mathrm{~min}$ followed by 30 cycles of $1 \mathrm{~min}$ denaturation at $94^{\circ} \mathrm{C}, 45 \mathrm{~s}$ annealing at $55^{\circ} \mathrm{C}$ and $1 \mathrm{~min}$ extension at $72^{\circ} \mathrm{C}$, and a final 5 min extension step at $72^{\circ} \mathrm{C}$.

In order to confirm the presence of a pentanucleotide microsatellite in the PCR samples, amplified products were cloned into the $\mathrm{pCR}^{\circledR} 2.1$ vector (TA Cloning kit, Invitrogen), according to manufacturer instructions. Clones were sequenced using the DYEnamic Dye Terminator Cycle Sequencing kit for MegaBACE (Amersham-Pharmacia). Obtained sequences were submitted to BLAST (Basic Local Alignment Search Tool) to search for identity with sequences deposited in GenBank ${ }^{\circledR}$.

\section{Heteroduplex assay}

Amplification of multi-loci microsatellite results in more than one fragment since the microsatellite loci is tandemly repeated in the genome, which makes it difficult to interpret the results.

An alternative approach to this problem is the use of a heteroduplex assay, which has been successfully employed previously (Roratto et al., 2006). This technique involves heat denaturation of PCR products, followed by slow cooling of the sample. During this step, doublestranded homoduplexes will form if the DNA strands are complementary, and if the sequences are different in one or more base pairs (because they are paralogous, i.e., they were amplified from different repeated loci), heteroduplexes will form. The greater the heterogeneity among microsatellite sequences, the higher the number of expected heteroduplex bands. The patterns of heteroduplex DNA can easily be accessed by the differential mobility of these molecules during electrophoresis, because of the single-stranded loops within the heteroduplexes, and can be seen as additional bands beside the homoduplex fragments.

The advantage in using heteroduplex assay in complex multi-loci microsatellite is the detection of homoplasic alleles, i.e., alleles with the same molecular weight but with different sequences.

The conditions for amplification of the microsatellite region and the cycling were carried out as described above, for the sequence isolation.

Prior to electrophoresis, amplified DNA samples were denatured at $95^{\circ} \mathrm{C}$ for $5 \mathrm{~min}$ and slowly cooled at room temperature for $1 \mathrm{~h}$ to allow heteroduplex formation. Products were analyzed by electrophoresis on $6 \%$ polyacrylamide gels and visualized by traditional $\mathrm{AgNO}_{3}$ staining.

\section{Statistical methods}

The presence or absence of each band in the gel was assigned 1 or 0 , respectively, allowing the identification of patterns or haplotypes for each individual analyzed. A phenetic matrix was constructed using these data, which was used for the cluster analyses. The numerical analysis of heteroduplex results was performed using the NTSYSpc program, version 2.0 (Rohlf, 1994). The Jaccard coefficient was used to obtain a similarity matrix, and UPGMA (Unweighted Pair Group Method Analysis) in module SAHN (Sequential, Agglomerative, 
Hierarchical and Nested clustering methods) was applied to obtain the corresponding dendrogram. A cophenetic value matrix was produced by COPH option and used by the MXCOMP module to measure the goodness of fit of a cluster analysis to the similarity matrix produced by SAHN. One specimen of Aegla uruguayana was used for comparison in the cluster analysis.

Analysis of Molecular Variance (AMOVA), implemented in Arlequin 3.5.1.2 software (Excoffier and Lischer, 2010), was used to determine the genetic structure of the populations. This analysis is based on variance components obtained from a Euclidean distance matrix between all pairs of individuals. The significance of these calculations is assessed by permutation procedures, in which individuals are randomly placed into different populations and groups.

By AMOVA, the Arlequin software calculates a $F_{\mathrm{ST}}$ value for each population pair, which ranges from 0 (indicating no differentiation between populations) to a theoretical maximum of 1 (although in practice this index is much less than 1 even in highly differentiated populations), and its significance is determined based on 1000 permutations. $F_{\mathrm{ST}}$ values were used for an indirect estimate of the effective number of migrants $(\mathrm{Nm})$ among populations through the equation: $N \mathrm{~m}=0.25\left(1 / F_{\mathrm{ST}}-1\right)$.

A model-based clustering method using multi-loci microsatellite genotype data to infer population structure and assign individuals to populations was done using a Bayesian approach performed in STRUCTURE (Pritchard et al., 2000). A non-admixture model with independent allele frequencies was used because studied populations are isolated from one another. No information about the population of origin for each individual was given. A series of three independent runs for $K$ (number of populations) from 1 to 6 was performed. The results are based on $10^{6}$ iterations, following a burn-in period of 500,000 iterations. Individuals were assigned probabilistically to populations or jointly to two or more populations if their genotypes indicate that they are admixed using the multi-loci microsatellite data.

\section{RESULTS}

\section{Morphological aspects of the animals}

No morphological differences were found among the individuals examined, independently of the population of origin, based on the diagnostic characters of Aegla longirostri.

\section{Microsatellite isolation}

A $245 \mathrm{bp}$-sequence was isolated, which showed no identity with other sequences in GenBank. However, an imperfect pentanucleotide microsatellite was found, showing the motif

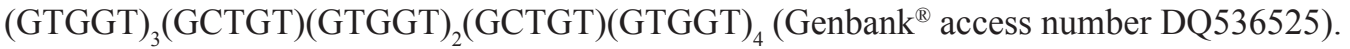

\section{Heteroduplex analysis of the pentameric microsatellite in $\boldsymbol{A}$. longirostri individuals}

Analysis of the A. longirostri PCR products by polyacrylamide gel electrophoresis after renaturation showed several bands of different mobilities from 140 to $410 \mathrm{bp}$, corresponding to heteroduplex DNA. The specimen of A. uruguayana showed bands from 130 to 375 bp. Forty-five different patterns (considered as haplotypes) were found for the 55 individuals analyzed, indicating a considerable intrapopulational variation (Table 2). Although some hap- 
M.L. Bartholomei-Santos et al.

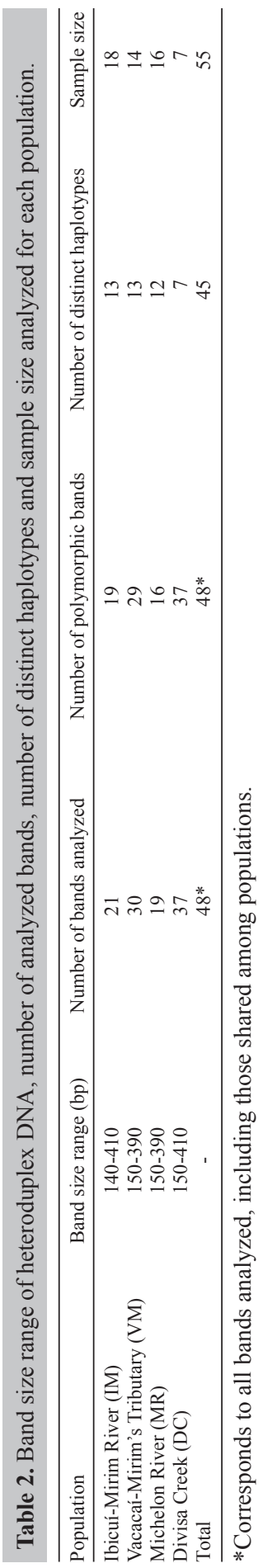

Genetics and Molecular Research 10 (4): 4133-4146 (2011) 
lotypes were present in more than one individual in a population, no shared haplotype was found to occur among populations, suggesting a high interpopulational variation.

DNA fragments amplified in independent experiments by PCR, using the same DNA sample and conditions, showed the same heteroduplex patterns, indicating that the patterns are reproducible for each individual (data not shown).

\section{Statistical analysis}

The cluster analysis revealed the grouping of individuals collected in the same locality, except for the individuals from the Vacacaí-Mirim tributary and from the Divisa Creek, which are grouped together (Figure 2). The dendrogram showed two large clusters, one composed by the population from the Ibicuí-Mirim River (group I) and the other (group II) subdivided into two clusters, II.1, grouping the individuals from Vacacaí-Mirim's tributary and Divisa Creek, and II.2, composed by the Michelon River population.

The cophenetic correlation between the cophenetic (ultrametric) value matrix and the similarity matrix using the Jaccard index (upon which the clustering was based) was 0.93 , indicating a very good fit of the clusters to the data.

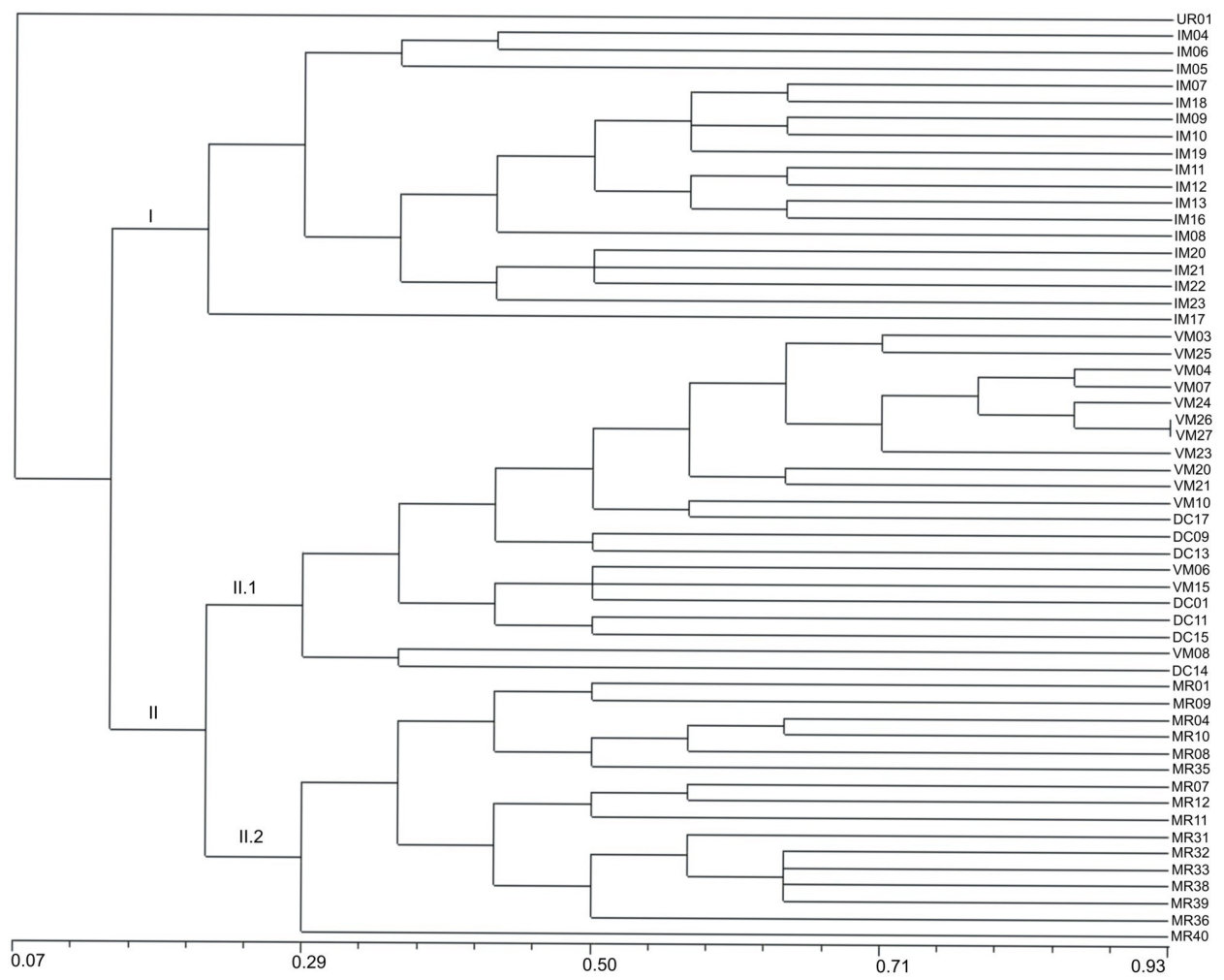

Figure 2. Dendrogram of the genetic relationships among populations of Aegla longirostri, constructed using Jaccard's coefficient and UPGMA clustering. UR = Aegla uruguayana IM = Ibicuí-Mirim River; VM = VacacaíMirim Tributary; MR $=$ Michelon River; DC $=$ Divisa Creek. 
The hierarchy used in AMOVA was based on the populations included in each one of the two basins (Ibicui-Uruguay: Ibicuí-Mirim River population - IM; Jacuí-Guaíba: Michelon River - MR, Vacacaí-Mirim tributary - VM and Divisa Creek - DC populations). Moreover, these groups agree with the clusters formed in the dendrogram (Figure 2). AMOVA revealed that most of the haplotype diversity was found within populations $(43.99 \%)$ than between the two groups $(28.03 \%)$ or among populations within groups $(27.98 \%)(\mathrm{P}<0.001)$ (Table 3). $F_{\text {CT }}$ value revealed that there was no significant structure between $A$. longirostri populations in Uruguay and Jacuí-Guaíba basins, although a considerable percentage of variation $(28.0 \%)$ could be observed between the two groups. On the other hand, $F_{\mathrm{SC}}$ and $F_{\mathrm{ST}}$ were highly significant showing that the main source of variation is in the lower hierarchical levels, predominantly within populations.

$\begin{aligned} & \text { Table 3. Analysis of Molecular Variance (AMOVA) for four populations of Aegla longirostri assessed by } \\
& \text { heteroduplex DNA. }\end{aligned}$
\begin{tabular}{lccc}
\hline Variation source & Variance components & Percentage of variation & $F$ \\
\hline Among groups (Uruguay Basin versus Jacuí-Guaiba Basin) & 2.70976 & 28.03 & $F_{\mathrm{CT}}=0.28031$ \\
Among populations within groups & 2.70508 & 27.98 & $F_{\mathrm{SC}}=0.38881^{*}$ \\
Within populations & 4.25233 & 43.99 & $F_{\mathrm{ST}}=0.56013^{*}$ \\
Total & 9.66717 & 100 & \\
\hline
\end{tabular}

$* \mathrm{P}<0.01$.

Values for $F_{\mathrm{ST}}$ between population pairs were highly significant $(\mathrm{P}<0.001)$ and extremely high, ranging from 0.14789 to 0.66379 (Table 4). The IM population was the most divergent $\left(\mathrm{F}_{\mathrm{ST}}\right.$ ranging from 0.45784 to 0.66379$)$. The populations $\mathrm{VM}$ and $\mathrm{DC}$ were genetically more closely related, although a moderate differentiation was found $\left(F_{\mathrm{ST}}=0.14789\right)$.

This genetic variability among populations reflects the gene flow estimate $(\mathrm{Nm})$ among them (Table 4). Nm values ranged from very low ( 0.12662 between IM and MR) to moderate ( 1.44045 between VM and DC), but only the latter was higher than 0.42 , indicating very low gene flow among populations (Table 4 ).

Table 4. The effective number of migrants $(\mathrm{Nm})$ between Aegla longirostri populations (above diagonal) calculated from pairwise $F_{\mathrm{ST}}$ (below diagonal).

\begin{tabular}{lcccr}
\hline Population & VM & MR & DC & IM \\
\hline VM & - & 0.27841 & 1.44045 & 0.19105 \\
MR & 0.47312 & - & 0.41649 & 0.12662 \\
DC & 0.14789 & 0.37510 & - & 0.29604 \\
IM & 0.56683 & 0.66379 & 0.45784 & - \\
\hline
\end{tabular}

The Bayesian method, implemented by STRUCTURE, revealed from the posterior probabilities $\mathrm{L}(\mathrm{K})$ and the second-order difference in $\operatorname{Ln}(P) D(K)$, that the most likely number of clusters to explain our data is $K=3$ (Table 5), indicating sub-structuring in our sample. The Bayesian approach showed a high genetic subdivision revealing one cluster for the population from the Ibicuí-Uruguay Basin (IM), one cluster for the population MR (Jacuí-Guaíba Basin) and one cluster which joined the populations DC and VM, both from the Jacuí-Guaíba Basin (Table 6, Figure 3). 
Table 5. Posterior probabilities of different cluster numbers $(K)$ calculated in STRUCTURE.

\begin{tabular}{lc}
\hline$K$ & $K \operatorname{Ln} P(D)$ \\
\hline 1 & -1.620 .2 \\
2 & -1.280 .3 \\
3 & -1.140 .2 \\
4 & -1.184 .4 \\
5 & -1.180 .1 \\
6 & -1.152 .6 \\
\hline
\end{tabular}

Table 6. Bayesian assignment test for $K=3$ without using any prior population information.

\begin{tabular}{lcccc}
\hline Population & Number of individuals & \multicolumn{3}{c}{ Inferred cluster } \\
\cline { 3 - 5 } & & 1 & 2 & 3 \\
\hline IM & 18 & 0.947 & 0.049 & 0.004 \\
VM & 14 & 0.000 & 1.000 & 0.000 \\
MR & 16 & 0.000 & 0.000 & 1.000 \\
DC & 7 & 0.000 & 0.872 & 0.128 \\
\hline
\end{tabular}

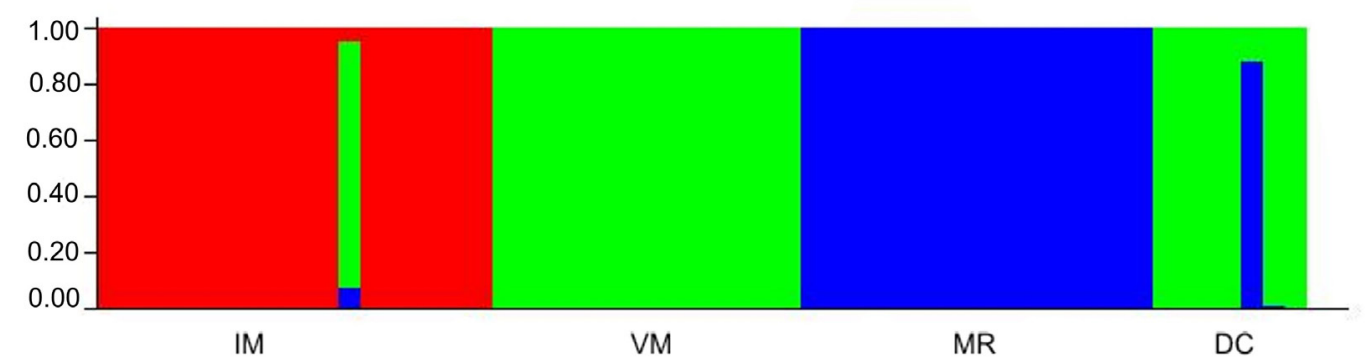

Figure 3. Likely ancestry of each Aegla longirostri individual, estimated using STRUCTURE. Each individual is represented by a line partitioned into segments corresponding to its membership coefficients in the three inferred clusters, and each color represents a different cluster. IM = Ibicuí-Mirim River; VM = Vacacaí-Mirim Tributary; $\mathrm{MR}=$ Michelon River; DC $=$ Divisa Creek.

\section{DISCUSSION}

Although no significant identity was found between the isolated sequence and the U1 snRNA gene sequences (except for the primer region), a pentanucleotide microsatellite was present in the Aegla longirostri amplified sequence, and the amplification pattern of several bands indicates that this repeat is possibly within a longer repeated region, as for U1 snRNA genes. In fact, in some organisms, microsatellites are associated with other repeats (Tero et al., 2006).

U1 snRNA genes are conserved genes present in eukaryotes and involved in the processing of the primary transcripts in the nucleus. They have been reported to be a complex consisting of tandemly repeated units, as in sea urchins (Brown et al., 1985) and taenids (Bretagne et al., 1991) or consisting of linked but not tandemly repeated units, as in mice (Marzluff et al., 1983) and humans (Bernstein et al., 1985). Possibly, the isolated sequence corresponds to a sequence that degenerated from an ancient U1 snRNA gene or pseudogene in the A. longirostri genome. In the human genome, pseudogenes of the small nuclear RNA genes are abundant (Denison et al., 1981). 
Multi-locus microsatellites, when found in a genome, are often considered as unsuitable for population studies. Counteracting this, the chosen molecular marker proved to be very sensitive, since high levels of genetic polymorphism was assessed with reproducibility in $A$. longirostri genome. Some studies were successfully carried out with this kind of molecular marker, using a heteroduplex assay (Roratto et al., 2006) or using automated genetic analysis for genotyping (Bart et al., 2006; Maillard et al., 2009; Knapp et al., 2010).

The usefulness of the heteroduplex assay was highlighted by the high number of haplotypes found in each population, which was reflected in a high proportion of haplotype diversity in the AMOVA analysis within populations (43.99\%) (Table 3). Despite this diversity, haplotypes from each population grouped separately from the other populations in the cluster analysis, except for individuals from Vacacaí-Mirim tributary and Divisa Creek, which formed one group (Figure 2). In accordance with these results, these two populations also showed the lowest differentiation, as reflected by the $F_{\mathrm{ST}}$ value $(0.14789)$ and the higher estimate of migrants per generation (1.44045) between them, compared with the other analyzed populations.

For the other populations, a substantial differentiation was found, with a low estimate of migrants per generation (Table 4). The differentiation among populations from the JacuiGuaíba Basin (east side) may be related to the distance separating them and to a possible low distance dispersion of $A$. longirostri in each generation. However, further analyses should be done to test this hypothesis. Aeglids have direct development and the juveniles remain with the mother for some time (Bueno and Bond-Buckup, 1996); this lack of a larval phase may restrict their dispersion.

Despite the short distance between the collecting points in Ibicuí-Mirim River and Michelon River (about $5 \mathrm{~km}$ ), these populations, which are separated by the Pinhal Range, showed the greatest differentiation $\left(F_{\mathrm{ST}}=0.66379\right)$. Moreover, the population from the IbicuíMirim River, the only one situated in the Ibicuí-Uruguay Basin (west side) showed the highest pairwise $F_{\mathrm{ST}}$ values. In the cluster analysis, the IM population was in one large cluster (I), separated from the other (II), which grouped the populations from the Jacuí-Guaíba Basin (east side) (Figure 2). On the other hand, analysis of molecular variance showed no significant structure between populations of the two basins, despite the considerable amount of variation found $(28.03 \%)$.

The Bayesian analysis was congruent with the results above, showing a cluster joining the two populations with the lowest $F_{\mathrm{ST}}$ and a clear differentiation among the other populations. Gene flow possibly occurred between individuals from VM and DC in a not so distant past. It is noteworthy that in Figure 3 one individual from IM presented ancestry from the VM + DC cluster. As the software STRUCTURE also calculates the fractional membership (inferred ancestry - $Q$ ) of each individual in each cluster (data not shown), this animal was identified as IM-17, which appears in the dendrogram (Figure 2) as the most differentiated sample, yet grouping in cluster I, which encompassed all animals from IM. It can also be observed in Figure 3 that one individual from DC (DC-14, data not shown) presented ancestry from MR population. These findings possibly reflect the common ancestry of the studied populations.

Such high level of genetic differentiation summed up to the lack of differences in the diagnostic morphological characters for the four $A$. longirostri populations might be indicative that some of these populations constitute cryptic species. Further studies involving other populations of this species and even other molecular markers would help to test this hypothesis. Several species of aeglids are threatened (Bond-Buckup et al., 2008; Pérez-Losada et al., 
2009) and cryptic species probably have a very narrow distribution, like most Aegla species, making them of significant conservation concern. This may be the case of the population occurring in Ibicuí-Mirim River, the southern limit of Atlantic Forest, which would be under threat considering its very restricted distribution range, among other factors. The identification and description of cryptic species have important implications for conservation and natural resource management (Bickford et al., 2007).

\section{ACKNOWLEDGMENTS}

We are grateful to MSc. J.V.T. Bitencourt, who participated in the sampling campaigns. We also thank CNPq (Conselho Nacional de Desenvolvimento Científico e Tecnológico) for a productivity grant to S. Santos (\#308723/2008-2).

\section{REFERENCES}

Abell R (2002). Conservation biology for the biodiversity crisis: a freshwater follow-up. Conserv. Biol. 16: 1437.

Bart JM, Knapp J, Gottstein B, El-Garch F, et al. (2006). EmsB, a tandem repeated multi-loci microsatellite, new tool to investigate the genetic diversity of Echinococcus multilocularis. Infect. Genet. Evol. 6: 390-400.

Bernstein LB, Manser T and Weiner AM (1985). Human U1 small nuclear RNA genes: extensive conservation of flanking sequences suggests cycles of gene amplification and transposition. Mol. Cell. Biol. 5: 2159-2171.

Bickford D, Lohman DJ, Sodhi NS, Ng PK, et al. (2007). Cryptic species as a window on diversity and conservation. Trends Ecol. Evol. 22: 148-155.

Bitencourt JVT, Roratto PA, Bartholomei-Santos ML and Santos S (2006). Comparison of different methodologies for DNA extraction from Aegla longirostri (Crustacea, Decapoda, Anomura). Braz. Arch. Biol. Techn. 50: 989-994.

Bond-Buckup G (2003). Família Aeglidae. In: Manual de Identificação dos Crustacea Decapoda de Água Doce do Brasil (Melo GAS, ed.). Edições Loyola, São Paulo, 21-121.

Bond-Buckup G and Buckup L (1994). A família Aeglidae (Crustacea, Decapoda, Anomura). Arq. Zool. 32: 159-346.

Bond-Buckup G, Jara CG, Pérez-Losada M, Buckup L, et al. (2008). Global diversity of crabs (Aeglidae: Anomura: Decapoda) in freshwater. Hydrobiologia 595: 267-273.

Bond-Buckup G, Jara CG, Buckup L and Bueno AAP (2010). Description of a new species of Aeglidae, and new records of related species from river basins in Argentina (Crustacea, Anomura). Zootaxa 2343: 18-30.

Bretagne S, Robert B, Vidaud D, Goossens M, et al. (1991). Structure of the Echinococcus multilocularis U1 snRNA gene repeat. Mol. Biochem. Parasitol. 46: 285-292.

Bretagne S, Assouline B, Vidaud D, Houin R, et al. (1996). Echinococcus multilocularis: microsatellite polymorphism in U1 snRNA genes. Exp. Parasitol. 82: 324-328.

Brown DT, Morris GF, Chodchoy N, Sprecher C, et al. (1985). Structure of the sea urchin U1 RNA repeat. Nucleic Acids Res. 13: 537-556.

Bueno AAP and Bond-Buckup G (1996). Os estágios juvenis iniciais de Aegla violacea Bond-Buckup \& Buckup (Crustacea, Anomura, Aeglidae). Nauplius 4: 39-47.

Cook B, Page T and Hughes J (2008). Importance of cryptic species for identifying 'representative' units of biodiversity for freshwater conservation. Biol. Conserv. 141: 2821-2831.

Denison RA, Van Arsdell SW, Bernstein LB and Weiner AM (1981). Abundant pseudogenes for small nuclear RNAs are dispersed in the human genome. Proc. Natl. Acad. Sci. U. S. A. 78: 810-814.

Excoffier L and Lischer HEL (2010). Arlequin suite ver 3.5: a new series of programs to perform population genetics analyses under Linux and Windows. Mol. Ecol. Res. 10: 564-567.

Feldmann RM (1984). Hamuriaegla glassneri gen. and sp. (Decapoda, Anomura, Aeglidae) from Haumurian (Late Cretaceous) Rock near Cheviot, New Zealand. New Zeal. J. Geol. Geophys. 27: 379-385.

Feldmann RM, Vega FJ, Applegate SP and Bishop GA (1998). Early Cretaceous Arthropods from the Tlayúa Formation at Tepexi de Rodriguez, Puebla, México. J. Paleontol. 72: 79-90.

Frankham R, Ballou JD and Briscoe DA (2004). A Primer of Conservation Genetics. Cambridge University Press, New York.

Hebert PD, Penton EH, Burns JM, Janzen DH, et al. (2004). Ten species in one: DNA barcoding reveals cryptic species in 
the neotropical skipper butterfly Astraptes fulgerator. Proc. Natl. Acad. Sci. U. S. A. 101: 14812-14817.

Jesse R, Schubart CD and Klaus S (2010). Identification of a cryptic lineage within Potamon fluviatile (Herbst) (Crustacea : Brachyura : Potamidae). Invertebr. Syst. 24: 348-356.

Knapp J, Bart JM, Maillard S, Gottstein B, et al. (2010). The genomic Echinococcus microsatellite EmsB sequences: from a molecular marker to the epidemiological tool. Parasitology 137: 439-449.

Leese F and Held C (2008). Identification and characterization of microsatellites from the Antarctic isopod Ceratoserolis trilobitoides: nuclear evidence for cryptic species. Conserv. Genet. 9: 1369-1372.

Maillard S, Gottstein B, Haag K, Ma S, et al. (2009). The EmsB tandemly repeated multilocus microsatellite: a new tool to investigate genetic diversity of Echinococcus granulosus Sensu Lato. J. Clin. Microbiol. 47: 3608-3616.

Marzluff WF, Brown DT, Lobo S and Wang SS (1983). Isolation and characterization of two linked mouse U1b small nuclear RNA genes. Nucleic Acids Res. 11: 6255-6270.

Mathews LM, Adams L, Anderson E, Basile M, et al. (2008). Genetic and morphological evidence for substantial hidden biodiversity in a freshwater crayfish species complex. Mol. Phylogenet. Evol. 48: 126-135.

McLaughlin PA, Lemaitre R and Crandall KA (2010). Annotated checklist of anomuran decapod crustaceans of the world (exclusive of the Kiwaoidea and families Chirostylidae and Galatheidae of the Galatheoidea). Part III - Aegloidea. Raffles Bull. Zool. 23: 131-137.

Meglécz E, Petenian F, Danchin E, D'Acier AC, et al. (2004). High similarity between flanking regions of different microsatellites detected within each of two species of Lepidoptera: Parnassius apollo and Euphydryas aurinia. Mol. Ecol. 13: 1693-1700.

Munoz JEG, Rodriguez A, Raso JEG and Cuesta JA (2009). Genetic evidence for cryptic speciation in the freshwater shrimp genus Atyaephyra de Brito Capello (Crustacea, Decapoda, Atyidae). Zootaxa 2025: 32-42.

Oliveira EJ, Pádua JG, Zucchi MI, Vencovsky R, et al. (2006). Origin, evolution and genome distribution of microsatellites. Genet. Mol. Biol. 29: 294-307.

Pérez-Losada M, Bond-Buckup G, Jara CG and Crandall KA (2004). Molecular systematics and biogeography of the southern South american freshwater "crabs" Aegla (decapoda: Anomura: Aeglidae) using multiple heuristic tree search approaches. Syst. Biol. 53: 767-780.

Pérez-Losada M, Bond-Buckup G, Jara CG and Crandall KA (2009). Conservation assessment of Southern South American freshwater ecoregions on the basis of the distribution and genetic diversity of crabs from the genus Aegla. Conserv. Biol. 23: 692-702.

Pritchard JK, Stephens M and Donnelly P (2000). Inference of population structure using multilocus genotype data. Genetics 155: 945-959.

Rohlf FJ (1994). NTSYS-pc. Numerical Taxonomy and Multivariate Analysis System. Version 1.80. Exeter Software. Setauket, New York.

Roratto PA, Bartholomei-Santos ML, Gutierrez AM, Kamenetzky L, et al. (2006). Detection of genetic polymorphism among and within Echinococcus granulosus strains by heteroduplex analysis of a microsatellite from the U1 snRNA genes. Genet. Mol. Res. 5: 542-552.

Rudolph EH and Crandall KA (2007). A new species of burrowing crayfish Virilastacus retamali (Decapoda: Parastacidae) from the southern Chile peatland. J. Crustacean Biol. 27: 502-512.

Russello MA, Stahala C, Lalonde D, Schmidt KL, et al. (2010). Cryptic diversity and conservation units in the Bahama parrot. Conserv. Genet. 11: 1809-1821.

Santos S, Bond-Buckup G, Peréz-Losada M and Bartholomei-Santos ML (2009). Aegla manuinflata, a new species of freshwater anomuran (Decapoda: Anomura: Aeglidae) from Brazil, determined by morphological and molecular characters. Zootaxa 2088: 31-40.

Silk N (2005). The Global Challenge of Freshwater Biodiversity Conservation. In: A Practitioner's Guide to Freshwater Biodiversity Conservation (Silk N and Ciruna K, eds.). Island Press, Washington, 1-9.

Tero N, Neumeier H, Gudavalli R and Schlotterer C (2006). Silene tatarica microsatellites are frequently located in repetitive DNA. J. Evol. Biol. 19: 1612-1619. 